Conference Draft (November 15 2010)

\title{
History Matters: China and Global Governance
}

\author{
By Wendy Dobson \\ Paper presented at PAFTAD 34: China's Role in the World Economy
}

Beijing, December 8, 2010

\begin{abstract}
This paper focuses on the two-way relationship between China and the international economic system. China's embrace of the global institutions and their rules and norms helped guide its spectacular economic growth and integration into the world economy. China's impact on the global economic order is still an open question, however. Its sheer size and dynamism makes it a force to be reckoned with. So far its influence has been largely constructive but recent signs of assertiveness in the Asian region and at home coincident with the 2012 leadership transition raise questions about the future. History matters to the answer. Memories of historical pre-eminence and humiliation drive nationalism and assertiveness at the same time that China identifies with developing countries as a counterbalance rather than as a leader or enforcer of the global norms and rules. The paper evaluates China's role in the regional and global economic institutions by applying a basic criterion of economic cooperation: is China willing to modify national policies in recognition of international economic interdependence? In the global institutions China does the minimum whereas in the region it has cooperated in safeguarding regional economic stability. Participation in the IMF demonstrates the complexities of China's re-emergence. China pursues its own interests in managing the exchange rate regime and accumulating foreign reserves, seemingly with little regard for the external consequences, at the same time that it advocates reforms in the international monetary system.
\end{abstract}


The profound transformation underway in the world economy passed another milestone in August 2010 when the Japanese government released its second quarter GDP numbers. These indicated that China's economy had overtaken Japan's in size to become the world's second largest economy after the United States. With India, the two most populous countries on the planet are successfully integrating into the world economy while the large advanced economies struggle with what is likely to be years of below-potential growth following the global financial crisis. So far, this shift in the center of economic gravity is remarkable in that, while not without bilateral tensions, relationships among the world's major states are both peaceful and collaborative in promoting common interests and collective action.

China's sheer size and dynamism are moving it to the top of many rankings (Box 1). It is the world's largest creditor and accumulator of foreign exchange reserves, the largest goods exporter and the largest importer of iron ore, copper, potash, timber products and Saudi crude oil. Some Chinese companies are now the world's largest by market capitalization. For thirty years it has been the world's fastest-growing economy. Its economic size relative to the United States has moved from 6 percent in 1990 to nearly 30 percent in 2005 and is on track to become the world's largest, the only question is whether this happens in the $2020 \mathrm{~s}$ or the $2030 \mathrm{~s} .{ }^{1}$ It is at the heart of the globalization of production with all major manufacturers of consumer goods and durables located there. Significantly, Chinese see themselves as returning to the center of the world economy, a position China held for centuries between 1300 and 1820 (Maddison 2006). ${ }^{2}$

The Japanese government's report, coming amidst struggles by US and European governments outside of Germany with slow growth, high indebtedness and unemployment, set off a wave of commentary on the implications of China's rapid rise for the post-unipolar world order. A month later, in September 2010, concerns about China's growing assertiveness with its neighbors were renewed by the flare up in the bilateral relationship with Japan after the latter arrested - and later released under surprisingly intense Chinese political pressure -- a fishing boat captain who had entered disputed waters in the East China Sea.

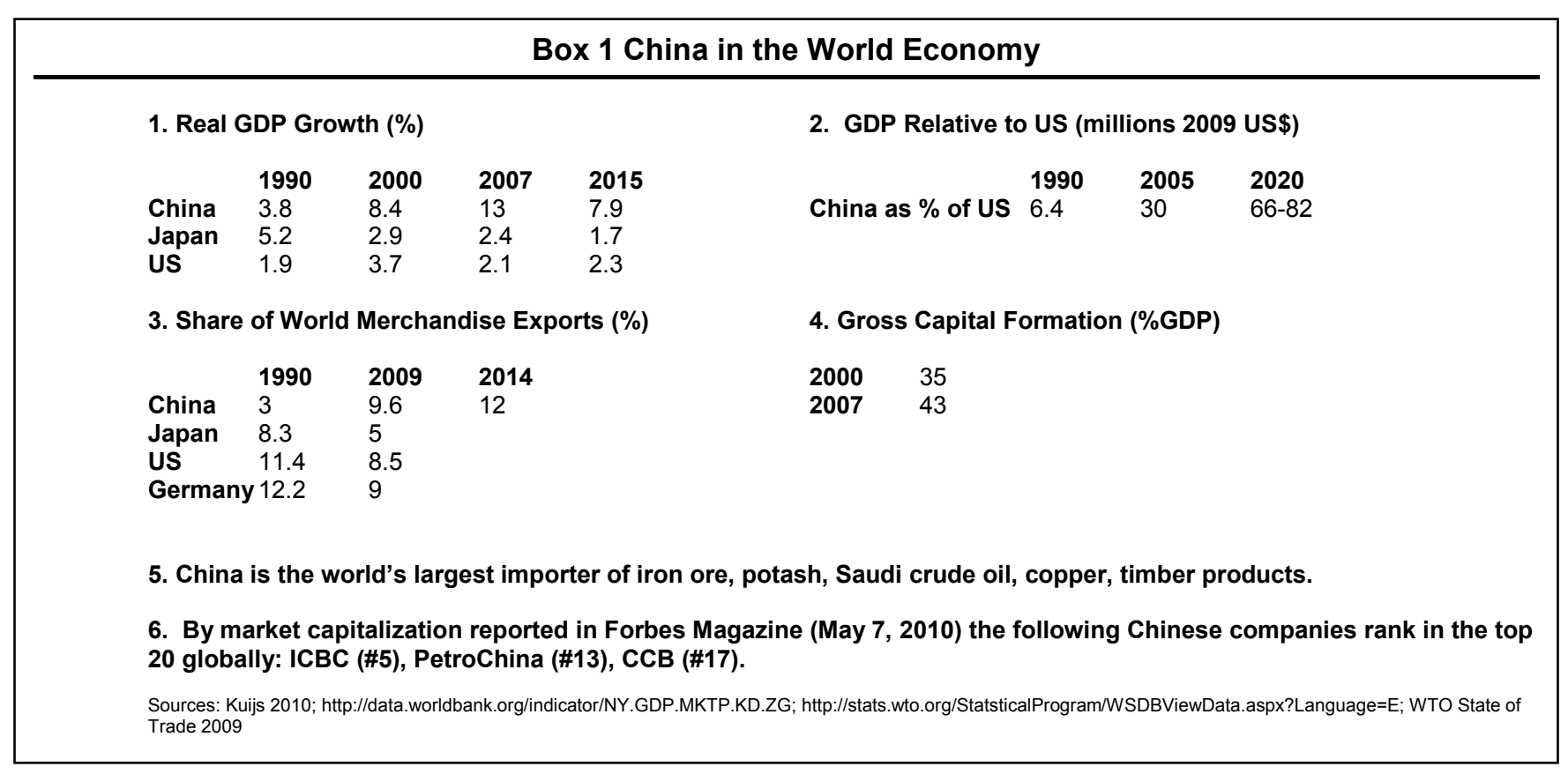


The focus on China's size and rising assertiveness tends to overlook a number of challenges and qualifications which temper predictions (Box 2). First, large as its economy may be China is still poor. Per capita income is less than a tenth that of Japan. Second, China's population is aging; the number of new labor market entrants is already shrinking and by 2030 the median age will be 41.1, higher than that in the United States. Growth will slow with the shifting age structure unless productivity growth compensates. Third, thirty years of rapid growth has generated rising internal imbalances that, as they are dealt with, will raise input costs; income inequality is rising (China's gini ratio is now higher than that in the United States), and environmental degradation is a rising public concern. Fourth, China's high investment/GDP ratio which has driven much of its growth cannot be sustained. Resources need to be reallocated from investment to China's low levels of consumption. Key factor inputs(energy, land, capital and the environment) are underpriced. Fifth, much of this under-pricing relates to China's distinctive mix of state and market institutions which have shaped and encouraged its rapid growth. Its financial sector, for example, is still bank-dominated and government-owned while its monetary system is shaped by a strong political commitment to exchange rate stability. Each of these factors must be taken into account in assessing China's prospects and the implications of its rapid rise.

\begin{tabular}{|c|c|c|c|c|c|c|c|c|}
\hline \multicolumn{9}{|c|}{ Box 2 China's Challenges } \\
\hline \multicolumn{3}{|c|}{ 1. Per Capita Income (end-2007, US\$) } & \multicolumn{4}{|c|}{ 2. Median Age } & \multicolumn{2}{|c|}{ 3. Income Inequality (GINI Index) } \\
\hline China & 2,430 & & & 2010 & 2020 & 2030 & & 2007 \\
\hline Japan & 34,310 & & China & 34.2 & 37.1 & 41.1 & China & 41.5 \\
\hline \multirow[t]{2}{*}{ US } & 39,932 & & Japan & 44.7 & 48.6 & 52.2 & India & 36.8 \\
\hline & & & US & 36.6 & 37.9 & 39.5 & $\begin{array}{l}\text { Canada } \\
\text { US }\end{array}$ & $\begin{array}{l}32.6 \\
40.8\end{array}$ \\
\hline \multicolumn{9}{|c|}{ 4. $\mathrm{CO}_{2}$ Emissions } \\
\hline \multicolumn{3}{|c|}{ A. $\mathrm{CO}_{2}$ Emissions (total kilotons) } & \multicolumn{6}{|c|}{ B. $\mathrm{CO}_{2}$ Emissions (metric tones per capita) } \\
\hline & 2005 & 2007 & & 2005 & 2007 & & & \\
\hline China & $5,609,477.7$ & $6,533,018.3$ & China & 4.3 & 5.0 & & & \\
\hline US & $5,836.473 .5$ & $5,832,194.0$ & US & 19.7 & 19.3 & & & \\
\hline World & $29,205,744.0$ & $30,649,360.0$ & World & 4.5 & 4.6 & & & \\
\hline
\end{tabular}

We have therefore a complex tapestry in the topic of China and global governance. The relationship is very much two-way. Looking back, China's remarkable development is inextricably linked to decisions to rely on the norms and rules as well as the advice and technical assistance from the global institutions. China's embrace of the global institutions and their rules helped guide its economic success in pulling millions of people out of poverty, creating millions of modern sector jobs and deepening its integration into the world economy. Tackling its relative poverty is a key driver in the story of China's economic ascent. Located in the neighborhood of the 'Asian miracle' and facing a Malthusian crisis in the 1970s following the upheavals of Mao's class struggles, the communist party leadership moved pragmatically to restore balance between population and economic production. Jobs became a central objective. As local experiments with decentralized rural production showed success governments moved to reform incentives throughout the country to draw in potential opponents who benefited from the status quo. 
Domestic institutions were then changed in ad hoc fashion that continues to this day. Industrial production benefited from foreign knowhow and capital, particularly from China's diaspora and East Asian neighbors, and in the late 1990s state-owned enterprises were radically restructured, opening the way for non-state firms which account for more than 80 percent of industrial production. The World Bank became involved following Deng Xiaoping's meeting with Robert McNamara around 1980 (Kent 2007; Zoellick 2010). The 15-year negotiation to join the World Trade Organization was instrumental in China's acceptance of the global rules of the road and a major driver of domestic policy reforms to change the planned economy, its institutions and its managers into more market-oriented ones. The strategy has had a spectacular payoff.

Looking forward, China's impact on the global economic order is still an open question. Its economic size and dynamism make it both 'systemically significant' and increasingly a political force to be reckoned with. Will that reckoning be peaceful? The Chinese people are strongly supportive of China once again taking its rightful place in the world and reversing two hundred years of conflict and humiliation by foreign powers. How will China participate in the world's economic and political institutions as it integrates into world markets? As its size and confidence grow will its behavior influence their goals and operations, for worse or better? More in its own image?

We are reminded by historians of earlier economic transitions that caused upheavals, such as the transition from British to US hegemony after the First World War when US economic policies took advantage of liberal trade policies in the United Kingdom. Japan's investment- and export-led growth after the Second World War caused major economic imbalances in the 1980s as the economy achieved greater systemic significance. The way these imbalances were dealt with by Japan and its major economic partners echoes in the minds of policy makers in addressing the international imbalances underlying the global financial crisis. The tendency to blame yen appreciation as the cause of Japan's decades-long stagnation is to misread history. The real culprits were mistakes in monetary policy and weak regulatory institutions (Corbett and Ito 2010; Posen 2010).

The rest of the paper is organized as follows. In the next section I explore the concepts of global and regional governance, views both inside and outside the country, of China's role in the world economy and how this role might evolve. The focus in the third section shifts to the debate about institutional reform in the context of the changing world economy. In the fourth section I examine China's approach to the provision of key public goods in the G20, the World Trade Organization (WTO), International Monetary Fund (IMF) and the World Bank, the Financial Stability Board (FSB) and in related regional institutions, including the debate about global rebalancing and China's exchange rate regime. Climate change is also included as the biggest collective issue of our time. Asian regionalism is the subject of the fifth section. China's behavior towards its neighbors, which until two hundred years it dominated peacefully through political and commercial relationships, will be a factor shaping the global order. The final section concludes and looks to the future. Will China play by the rules, assert its own perspectives or change the regime? The transition underway in the top political leadership raises many questions about China's future role. Signs of growing assertiveness in its view of its global responsibilities relative to the United States and Europe, more assertive relationships within Asia and in the treatment of foreigners in China, suggest these are still open questions. 


\section{Global Governance and Chinese Perspectives}

At its most abstract global governance is the rule making and exercise of power on a global scale by entities working within organizations functioning on democratic principles and accountability (Keohane 2002). These entities include governments, corporations, individuals, civil society organization and other non-state actors. Joint action in these institutions is based on common interests and values; members agree to abide by common rules and shared work of the institutions. The institutions in turn are accountable to their members.

Global economic governance, the main focus of this paper, was established in the postwar period through the Bretton Woods institutions (IMF and World Bank), WTO, the Basel financial institutions centered at the Bank for International Settlements and the G7 leaders' summits established by French and German leaders in 1975. In these institutions governments cooperate to produce non-rivalrous 'international' public goods from which no one can be excluded and which no government can produce by acting on its own. More broadly these public goods include peace, law and order, open and efficient markets, economic and financial stability, freedom from poverty or communicable disease and a clean environment.

As economies have become more interdependent, governments have cooperated in promoting and maintaining economic and financial stability -- even coordinating economic decision making -- in theory to modify national policies in recognition of international economic interdependence. This definition of economic policy coordination can be used as a benchmark to evaluate the extent to which governments alter policies either in response to peer pressures or in recognition of the consequences of spillovers. This does not mean governments give precedence to international over domestic goals. But coordination or cooperation is a way of expanding choices available to national policy makes because it gives them influence over policy choices of other cooperating governments. Further, while collective action involves ceding some national sovereignty, in deciding to cooperate governments exercise sovereignty (Dobson 1991).

Relations among national governments can be seen as ranging along a spectrum from conflict to independent action to supranational integration where governments set policies in a forum to which they have ceded significant authority (Box 3).

\section{Box 3. The conflict-independence-integration spectrum}

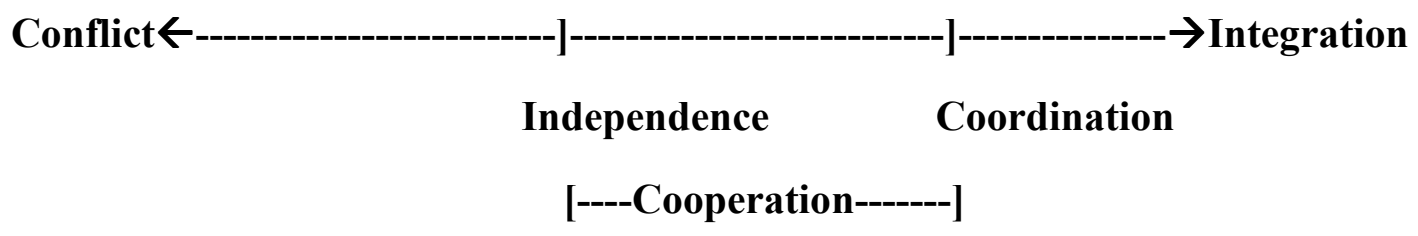

The Bretton Woods institutions were created by the western alliance after the Second World War and operate on principles of governance common to the founding democracies: 
market competition, transparency and the rule of law and respect for human rights. Since the end of the cold war in the early 1990s, however, these institutions have come to be regarded as exclusive clubs suffering from democratic deficits; their limited membership and mandates prevented them from responding adequately to the growing systemic significance of China, India and Brazil whose policies and performance could spill over onto their neighbors and trading partners. These dynamic new players require voice commensurate with their growing economic importance.

Predictions of China's future international role cover the spectrum from conflict to cooperation. Some optimists who are persuaded by China's historical role and its sheer size predict a China so powerful that the world order is reshaped and China acts independently. China asserts values based on its own traditions, returning to the tributary system in East Asia and inevitably challenging the United States for global pre-eminence (Jacques 2009). Others see China's future transformation into an urban, green and innovative society driving a more assertive international role in securing natural resources, building soft power, taking a higher profile in international organizations and changing the rules of the game (Economy 2010).

Pessimists discount China's future influence because of the exigencies of rising economic inequality, environmental degradation and the weak financial system which will preoccupy it at home for the foreseeable future, just as domestic preoccupations have caused it to turn inward in the past (Friedman 2009; Pei 2009; Bardhan 2009). Intermediate positions argue that most modern societies now accept that a stable world order is based on key western principles of democracy, the rule of law and social justice. The challenge in the post-unipolar world is to apply these principles in pragmatic ways through partnerships with emerging powers that recognize cultural differences (Mahbubani 2008). China accepts and participates in this world order, seeing itself more as a counter balance to other major powers and primarily focused on its huge domestic economic challenges (Dobson 2009a).

Too often the popular debate is framed in zero-sum terms. Political and security analysts tend to conflate economic with hard power and assume relationships among great powers are zero-sum. Yet economic power is not simply the absolute size of an economy but the ability to get others to change their positions through economic threats and persuasion such as freezing bank accounts, distributing bribes and exerting other forms of influence that others emulate (Nye 2004). Political analysts also think in euro-centric historical concepts of empire, primacy and imperialism and predict conflicts with zero-sum outcomes in which China 'wins' and the United States 'loses' (as do China's two huge Asian neighbors Japan and India, which are also assumed to compete for domination). China's search for new sources of natural resource commodities adds to these perceptions (China's rising FDI and government aid to such producers in Africa and Central Asia, for example). Calls from nationalists within China advocate more assertive behavior in the region and the greater exercise of power in the world commensurate with its growing size. Some Americans predict inevitable bilateral conflict (Kagan 2008).

The official American view is both pragmatic and positive sum as expressed by President Obama's November 2009 Tokyo speech: 
...in an interconnected world, power does not need to be a zero-sum game, and nations need not fear the success of another. Cultivating spheres of cooperation - not competing spheres of influence will lead to progress in the Asia Pacific.

... .America will approach China with a focus on our interests... important to pursue pragmatic cooperation with China on issues of mutual concern, because no one nation can meet the challenges of the 21st century alone, and the United States and China will both be better off when we are able to meet them together. That's why we welcome China's effort to play a greater role on the world stage -- a role in which their growing economy is joined by growing responsibility. China's partnership has proved critical in our effort to jumpstart economic recovery. China has promoted security and stability in Afghanistan and Pakistan. And it is now committed to the global nonproliferation regime, and supporting the pursuit of denuclearization of the Korean Peninsula. So the United States does not seek to contain China, nor does a deeper relationship with China mean a weakening of our bilateral alliances. On the contrary, the rise of a strong, prosperous China can be a source of strength for the community of nations (US White House 2009).

Secretary of State Hillary Clinton in her September 2010 New American Moment speech (Clinton 2010a) and elsewhere has elaborated this view, emphasizing that US leadership will rely on partnerships based on principles of shared responsibility.

\section{Chinese Perspectives on the Global Order and China's Role}

There is no single "China Inc." view or voice on these issues. One evident cleavage in Chinese debates is between the military, intelligence and security communities and the economic managers and internationalists. The former are increasingly vocal about China's growing clout and favor more assertiveness, particularly at home and in the region. There is also public support for the proposition that the Chinese economy is sufficiently robust, demonstrated by its successful navigation of the global crisis, that China should be more assertive in the world and reverse its history of humiliation in the region. Economic managers and internationalists are much more cautious. They recognize that China's economic institutions are still evolving, the economy has vulnerabilities and growth will slow in the years ahead as a result of the restructuring and rebalancing envisaged in the $12^{\text {th }}$ Plan.

In the early years after the founding of the People's Republic in 1949, China was hostile to global institutions and governance. Although a founding member of the United Nations, the existence of both Beijing and Taipei administrations caused a UN debate lasting until 1971 over who should take the seat. Membership in the scientific and technical organizations followed, including in the World Bank and the IMF. In all these difficult negotiations, China's self-interest and considerations of sovereignty (particularly with respect to Taiwan's membership) were front and center (Kent 2007:33-64). By 1978 when its economic transformation began the Chinese leadership recognized that in the age of globalization there was little choice but to integrate into the international economy - and its institutions - in order to modernize itself.

China is a member of the Security Council but its role in the United Nations reflects its multi-faceted view of itself: "back" as a major power, still-poor but pursuing its own interests 
which may include counter-balancing the United States on such security interests as Iran and North Korea. At the same time China argues it is still a poor developing country measured by per capita GDP. As a developing nation it is committed to universal UN membership but should not be expected to take responsibility for the rest of the world. Instead China expects to do the minimum while pursuing its goals for the economic growth and job creation necessary to maintain political and social stability.

This focus was not arrived at lightly. Since the 1990s party leadership has spent much time studying the benefits and costs of economic globalization before deciding to open up in ways that preserve Chinese autonomy. Joining the WTO in 2001 required China to conform to international rules and norms; accordingly, major changes were made in China's domestic regimes. ${ }^{3}$ At the same time, changes were made to manage the perceived risks of greater openness to domestic economic security, national sovereignty and domestic political and cultural values that could weaken national governance. Foreign investors were denied access to the pillar industries (energy, communications, finance, education and mass media) and the speed of change in key prices such as the exchange rate was to be gradual and controlled; China would also more actively promote its own cultural values (Yu Keping 2009). Expressing its sovereignty, the government signed more than a thousand bilateral and multilateral treaties between 1998 and 2002, participated in anti-terrorist actions, pushed negotiations along with North Korea, founded the Shanghai Cooperation Organization and proposed the strategy of harmonious development (Yu Keping 2009).

Chinese scholars also describe China as a regional power with limited global interests; one that will take on a greater cooperative profile in East Asia. There is an explicit acceptance in China of a central precept of East Asian development that regional political stability has made it possible to focus exclusively on economic development. Wealth, not bullets, is the route to power and influence. As a growing regional economic power it will exert its political influence there and open its markets to serve as the regional locomotive by making opportunities for its neighbors (Zhang and Tang 2005).

In 2006 President Hu Jintao set forth China's principles for peaceful development in an harmonious world (hexie shijie) that included independence, self reliance and peaceful coexistence in which differences are respected and security is based on mutual trust, benefits, equality and cooperation. These principles were proposed as an alternative vision of global governance and imply several criticisms of western principles:

- The status quo order is "undemocratic"; the democratic deficit in international institutions, dominated by western nations and serving their own interests, (and tolerating US unilateralism) should be reduced;

- North-South economic disparities are growing and the wealthy advanced nations practice double standards in which they expect concessions from developing nations that are not

\footnotetext{
${ }^{3}$ To join the WTO thirty central ministries and departments were directed in 2002 to change 2300 laws and regulations (eliminating many of them) and 100,000 local laws and regulations at the provincial and automous region levels (Yu Keping 2009:153).
} 
reciprocated. These disparities should be reduced through "shared development and common prosperity".

- Countries have differing histories and cultures and therefore differing political systems and economic models. The international system should observe diversity and tolerance and countries should not interfere in each other's affairs but seek "reconciliation amid differences".

- Cross border crises and conflicts should be resolved through cooperation rather than the use of force (Wang and Rosenau 2009).

These principles also imply that the United States should become a "normal" country, abide by international law and it and other western countries should open their markets more to developing countries. There should also be greater reliance on the UN system in multilateral diplomacy. These principles have much in common with western principles in recognizing the need for international regimes and respect for universalistic values of justice, fairness and mutual assistance.

Chinese perspectives are deeply influenced by historical experience. China supports noninterference and democratic processes and does the minimum, claiming to be a still-poor developing country. These positions are understandable in the historical context but are inconsistent with China's re-emergence as a major economic power in an interdependent globalized world. As a major power China is expected to observe - and enforce - global rules and norms and to adopt or even modify national policies in recognition of interdependence. Reforms of the economic institutions to give China more voice are seen as a way to encourage such behavior.

\section{Reforming the Global Institutions?}

While there is consensus on the need for such reform there is not yet consensus on what to do. The WTO and IMF are seen as flawed in their mandates and operation. The WTO's single undertaking approach to multilateral negotiations makes the rounds increasingly difficult to manage with such a large and diverse membership. The Asian economies' trust in the IMF as manager of balance of payments crises was shredded during the Asian financial crisis and countries have since moved to self-insure by building their foreign exchange reserves. Views on what to do range across a spectrum from improving the status quo, to creating new centralized institutions suggestive of global government, or greater decentralization of the existing institutions.

These proposals are usefully considered in the context of the pressures on the institutions from key transformations underway in the world economy. First, while the nation state remains the central player in collective action, a diversity of other interests and players has emerged including businesses, individuals, civil society and social organizations, criminal networks and terrorists, and cross-border coalitions that are interconnected through information technologies. Second, the sources of rivalry and instability are changing: $19^{\text {th }}$ century armed conflicts resulting from military rivalries and territorial ambitions are being replaced by large populations aspiring to higher living standards pressing inexorably on the global commons, resources and 
infrastructures; pressures for cross-border migration are growing and by market concerns such as market access, treatment of foreign investors, access to technology and industrial espionage.

Third, in this environment of greater diversity and changing threats the traditional topdown approach is declining in effectiveness and legitimacy. The Bretton Woods institutions are being pressed towards universal membership and consensus decision making, similar to the United Nations, to increase legitimacy. But the fallouts of consensus decision making are reduced ability to reform themselves and to take effective and timely actions.

Fourth, global leadership is in flux. American leaders' commitments to continued global and regional leadership notwithstanding the United States will become a 'frugal' superpower as it grapples post-crisis with a huge long-term fiscal imbalance. US responses to the two big challenges to the global commons, climate change and the global financial crisis, are driven more by domestic than global interests, a failure which has caused disillusionment with US leadership of the world economic order. There is a paradox between rising pressures on the global commons which require strong leadership to address and the reality that there is no single dominant state which can deliver. As Clinton argues partnerships, networks and minilateral agreements are parts of the way forward. The US role in the outcome will be crucial, but not decisive.

In the wake of the global financial crisis support for more centralization has come from the UN Commission of Experts on Reforms of the Monetary and Financial System (2009) which proposed new organizations based on the universal membership of the United Nations. French President Sarkozy also advocates more centralized financial regulatory institutions. But most governments are unwilling to cede sovereignty to a global super-regulator in the belief that good regulation begins at the national level by strengthening the prudential oversight of financial institutions to ensure their safety and soundness. The size and reach of global regulators cannot make up for the local knowledge and judgment of national regulators who must be very knowledgeable about the institutions they oversee.

Decentralizing the institutions is another option and here we find two kinds of proposals. In one the international organizations become hubs for more decentralized networks of member countries with common interests, regardless of location. The alternative is decentralization along regional lines.

Robert Lawrence argues that a more decentralized WTO will better accommodate the diverse membership, better achieve the central mission of deeper economic integration and alleviate its growing institutional problems (Lawrence 2006). His club-of-clubs proposal sees the entire membership involved in rule making but they would not have to join agreements that groups of members with similar interests might negotiate. All members would still use the dispute settlement mechanism but any penalties would apply only to the 'club' agreement which was violated. Eichengreen (2009) suggests a World Financial Organization analogous to the WTO but with a more decentralized structure whose membership would be obligatory for countries whose financial institutions wish to engage in cross-border activities. The organization would set standards and rules for supervision and regulation with each member having room to tailor regulation to the structure of their financial markets. An independent body of experts 
analogous to WTO dispute settlement panels would monitor whether countries have met their obligations and impose penalties for poor performance.

Kawai and Petri (2010) argue that while provision of the public goods supplied by the WTO, IMF, World Bank and Financial Stability Board would still be global these institutions would coordinate the supply of related services by regional institutions in which countries in the region are the decision makers. This innovation implies the principle of subsidiarity by which activities are carried out at the level at which they are most effectively produced but accountability is to the global rules. It also supports the concept of competitive supply and evolving membership is arrangements according to common interests.

Little movement is discernible in either direction, although in regional finance the multilateralized Chiang Mai Initiative (CMIM) is a step towards an Asian Monetary Fund and the European Central Bank has created the European Financial Stabilization Fund to mitigate the recent sovereign debt crises. The central issue is that while these mechanisms address the democratic deficit, questions of effectiveness remain. The regional decentralization proposal has particular risks in Asia which is unique in that it is home to three of the world's largest economies and who also mistrust each other. East Asians are anxious to retain US engagement in the region as a hedge against China; their attempts to channel rivalries among the giants into regional cooperation are positively received but competition continues outside and behind the scenes.

\section{Global Economic Governance and China's Role}

The 2008-09 financial crisis highlighted the interconnectedness of the global financial system. The United States and Europe were at the crisis epicenter. When aggregate demand dried up as households and businesses began to repair their balance sheets the effects of the recessions cascaded through global supply chains to the Asian economies. Asia's financial institutions, having undergone reform following the 1997-98 crises, escaped the worst of the financial crisis but its producers suffered heavily from the disappearance of final demand in US, European and Japanese markets.

The severity and global spread of the crisis also opened a window for a long overdue and pragmatic overhaul of global summitry. Leaders had no choice but to meet in the depths of the crisis in November 2008. G20 finance ministers and central bank governors had already begun to meet following the Asian crisis and so elevating G20 meetings to the leaders' level was an obvious choice. Most (but not all) of the leaders of the world's twenty largest economies are members. They managed the crisis and used the international institutions to implement their decisions.

As Robert Lawrence has argued, effective international economic institutions not only require a balance between their openness, diversity and cohesion, they require the means to carry out their roles. But lacking effective mechanisms of enforcement they must rely on peer pressure. At the 2009 meeting in Pittsburgh the G20 formalized their agenda to include a framework for balanced and inclusive growth, financial regulatory reforms, resuscitating the global trade negotiations and growth that includes smaller developing countries not represented in the G20. 


\section{The G20}

At their initial meetings G20 leaders tasked the IMF with providing appropriate liquidity to requesting countries and reforming its governance better to reflect the changing shape of the global economy; the WTO was tasked with concluding the Doha round, while the World Bank was tasked with addressing poverty in developing countries. The Financial Stability Forum's membership was expanded and upgraded to a Board.

As the world's largest exporter and owner of the largest foreign exchange reserves China expects, and is expected, to be active in the G20's focus on current account imbalances. China has been in the hot seat over its managed exchange rate and the huge buildup of foreign exchange reserves far beyond levels necessary to cover import requirements (Figure 1 and Table 2). Since 2008 China has played as constructive a role as domestic politics would allow, advancing a proposal to move to the SDR as the world's reserve currency, a move that would serve its own interests as well as the global interest. The central bank moved modestly towards greater nominal exchange rate flexibility in 2010 when it dropped the de facto peg to the US dollar and allowed further appreciation in the months following. At the Seoul summit China withstood intense US and other pressures to modify the exchange rate regime. ${ }^{4}$

At the Toronto summit President Hu Jintao outlined his views of G20 priorities in words that imply support for the existing global institutions and a desire to see them work better:

- a "guiding role in shifting international economic cooperation towards "...long-term perspective...from coordinating stimulus measures...to promoting long-term governance and from passive response to proactive planning."

- "...accelerate(s) the establishment of a new international financial order that is fair, equitable, inclusive and well-managed...." and "...that is good for the growth of the real economy"; and

- Builds "... an open and free global trading regime....reject all forms of protectionism and unequivocally advocate and support free trade" (Xinhua 2010a).

But these pronouncements have not penetrated Chinese officialdom. Informal reports from officials in summit host countries note Chinese officials' relative passivity towards, even lack of apparent interest in, preparatory negotiations.

Regionally, G20 issues were discussed at newly-constituted leader summits among China, South Korea and Japan. But six Asian countries (Australia, China, India, Indonesia, Japan and South Korea) plus Russia are members of the G20 and one might have thought they would consider some kind of regional coalition in preparing for the plenaries. But beyond multilateralization of the Chiang Mai Initiative national treasuries and central banks responded to the crisis in uncoordinated fashion. There was no collective Asian strategy that pulled together the domestic, regional and global impacts of the large stimulus packages in China, India and Japan and other members. No prescriptions were forthcoming from the group and no targets for their own cooperation.

\footnotetext{
${ }^{4}$ While accelerating the pace of nominal appreciation just prior to the summit.
} 
Instead China pursued its main interest in gaining greater voice in the institutions by joining dialogues organized by other large economies, Russia and Brazil, which called for "democratic and balanced global governance" giving developing countries an active voice in defining their own futures; dialogues that trumped any regional initiatives. ${ }^{5}$

\section{The WTO, Trade and Investment Liberalization and Dispute Settlement}

While the G20 was founded in part to include it as an equal player, China had to work long and hard to join the WTO in 2001. It had to accept designation as a non-market economy in antidumping and safeguard cases and agree to annual compliance reviews. Even so, China has been a major beneficiary of the rule-based international trading regime. Almost 80 percent of industrial production now originates in non-state firms; trade accounts for nearly 40 percent of GDP; it is the world's largest merchandise exporter, the leading emerging market destination for foreign direct investment (FDI) and an increasingly important source of outward FDI. It is an active participant in the WTO dispute settlement mechanism, where it is complainant in seven cases, respondent in 18 cases and participant as third party in $69 .^{6}$

Yet China has been a relatively passive player in WTO governance. The Doha Development Round has languished far beyond its targeted 2005 completion date because its centerpiece is difficult issues left over from previous rounds while new concerns like green protectionism, rising commodity prices and financial instability have marginalized its agenda. The single undertaking adds to the difficulties of concluding an agreement among the large and diverse membership. Business interest in the round is difficult to find. Powerful farm lobbies in the United States and India played roles in the breakdown in July 2008. China sided with India's demands based on its own interest groups regardless of the impact on the institution.

At the outset of the Doha round China argued that it had 'already given' in the accession talks; this was a reasonable position at the time but now a decade has passed. As a major beneficiary of the regime it is reasonable to expect China to provide a new offer such as its recent proposal to join the government procurement agreement, nine years after it promised to do so (Anderlini and Betts 2010).

Instead China has focused on regional trade agreements (RTAs). Most of China's regional trade is in goods and much of the liberalization is tariff reductions; difficult non-tariff barriers receive less attention yet they matter to services trade. ${ }^{7}$ Studies also show that subregional agreements produce outcomes that are inferior to region-wide RTAs or to agreements

\footnotetext{
${ }^{5}$ China participated in BRIC meetings and the BASIC talks consisting of Brazil, South Africa, India China, and in dialogues including India, Brazil, South Africa and Mexico (Xinhua 2010b).

${ }^{6}$ Details can be found at http://www.wto.org/english/tratop e/dispu e/dispu by country e.htm accessed July 16 2010 .

${ }^{7}$ More than half of Asia's merchandise exports are now shipped within the region. But it remains heavily dependent on external markets for final demand. Analysis of Asia's intraregional exports in 2006 shows that while 48.2 percent of Asia's exports were shipped to Europe and North America when parts and components were taken into account the share rose to 67.5 percent (Asian Development Bank 2008:71).
} 
among the large countries (Park and Cheong 2008). Quantitative studies have shown that the liberalizing gains increase with the size of the agreement (Kawai and Wignaraja 2009).

With the exception of its bilateral FTA with New Zealand, China's RTAs reveal more of an interest in foreign policy objectives than economic liberalization (Table 1). The ChinaASEAN agreement (CAFTA) was a friendly initiative aimed at increasing bilateral market access with East Asia's "core" economies. It took effect on January 1, 2010 and covers an estimated $\$ 4.5$ trillion in trade volume with 90 percent of goods to be traded tariff-free. Problems lie ahead, however. Usually the gains from trade are realized through specialization, differentiation and increases in intra-industry trade. But the structure of China's two-way trade, particularly with Indonesia and the Philippines, is very similar and therefore competitive rather than complementary. In contrast, these countries gain through complementary trade with Japan, South Korea and the United States.

China has shown little interest in APEC proposals for a Free Trade Area of the Asia Pacific (FTAAP) because of potential US involvement. Yet the United States is now pushing the Trans-Pacific Partnership (TPP), a comprehensive high-quality free trade agreement spearheaded by New Zealand, Chile, Singapore and Brunei Darassulam and open to any country wishing to join - which the United States, Australia, Peru and Vietnam have applied to do. The resulting 8country negotiation of TPP will figure prominently in the leadup to the US-hosted APEC leaders' meeting in 2011 in Honolulu when President Obama has committed to complete the negotiation. This negotiation is also envisaged to create a baseline in its standards and comprehensiveness with which other applicants will be expected to comply. The ultimate benefits of the TPP will depend on the other large Asian economies joining (USTR 2009). China has shown no interest; instead pursuing its own agreements with Japan, South Korea and Australia (China's 2005 proposal for a negotiation with India has so far led nowhere). Progress is slow since its trading partners are committed to comprehensive liberalization. And it is unclear how the TPP and other proposals for regional FTAs will play out.

Thus China is a major beneficiary of the open world trading regime but is doing little to maintain the system. It could re-energize the Doha round by joining the government procurement agreement, engaging in sectoral liberalization agreements and pushing the services liberalization talks (services now account for 40 percent of GDP). In return, the United States and the advanced economies should respond to China's desire to be recognized as a market economy and end the humiliating annual compliance reviews (Hufbauer and Lawrence 2010). Within the region, China also faces contradictions between its economic size and dynamism and its domestic preoccupations. Developing countries feel the competitive pressures of its managed currency; it is foot dragger on region-wide liberalization which all studies show provides the largest overall benefits. This issue is made more complex because the smaller economies benefit from access to the US market and see its presence as a hedge against Chinese dominance.

\section{Investment Liberalization}

Compared to the trade regime China is asserting its interests more strongly with respect to direct investment and the treatment of foreign nationals in China, raising questions about whether domestic interests will trump international rules. In the absence of an international investment regime countries negotiate their own agreements for non-discriminatory treatment of 
foreign investors and the treatment of foreign citizens. China's policies have explicitly encouraged FDI inflows since the special economic zones were set up in the 1980s. China precommitted in the WTO accession talks to open its service industries, particularly financial services, to foreign entrants after a designated phase-in period. Since the 'Going Out' strategy was introduced large enterprises and the main sovereign wealth fund, the China Investment Corporation, have become active international investors and acquirers of real and financial assets. The shock of the global crisis, which saw many foreign investors lay off Chinese workers or even abandon their investments, strengthened the Party's resolve to reduce reliance on foreign technology and diversify sources of commodity supply. The 2015 S\&T strategy encourages innovation and patenting and imposes new requirements on foreign multinationals, weakens IP protection and relies on discriminatory government procurement policies, all of which have fanned fears of a new nationalism in Chinese policies.

In the natural resources industries China's behavior needs to be viewed in the larger context both of its interests in attracting foreign knowhow through FDI and its goals for sourcing natural resource commodities and extending the business strategies of its multinationals abroadand how these firms are treated abroad. With the conviction and imprisonment of two foreign nationals, one Australian and the other American, on charges of bribery (the first case) and violating laws on state secrets (in both cases), serious questions have been raised about the interrelationships among business, politics and the Chinese legal system. In both cases foreign governments have argued that the lack of transparency in the legal process violated China's own bilateral consular agreements and its own laws about consular rights (Cohen 2010).

China's frustrations with the international iron ore cartel help to explain the first case because the cartel has shown little price flexibility in recent negotiations with China, its largest customer. Two other factors are also at issue: frustrations with the Chinese Aluminum Company's (Chinalco) lack of success in acquiring certain assets of Rio Tinto, an Australian cartel member, and frustration with alleged activities in China by Rio Tinto employees that undermined the authorities' attempts to consolidate the fragmented steel industry's position in the negotiations. Chinese actions were a pointed warning.

A further dimension of the resources issue is the suspicion with which Chinese SOEs are treated when they invest abroad. Resource-seeking FDI is one of the least-sophisticated forms of FDI; resource companies invest upstream in exploration activities to expand available supplies or they make acquisitions to access existing sources of supply for their own uses. A recent study of sixteen cases of outward FDI concludes that less than 20 percent of the cases (in Angola, Nigeria and Russia) were intended to tie up sources of supply for Chinese use (Moran 2010).

Chinese investments and acquisitions are largely made by huge SOEs raising questions, particularly in the advanced economies, about whether their key decisions will be driven by commercial or political objectives. Some light is shed on this question in a recent study of the CNOOC bid for Unocal in 2005 (Steinfeld 2010). CNOOC's main objective was commercial; the negotiations were carried out along commercial lines and the involvement of bureaucrats was minimal. China did not even have an energy ministry at the time. The fragmented bureaucratic structure does not suggest China Inc. Rather company behavior suggests intense competition within a domestic oligopoly; one that is struggling to master the international rules of the mergers and acquisitions game whose rules are set by international stock exchanges. 
Suspicion and mistrust are also rife in the telecommunications industry. China's national innovation strategy provides fiscal and other incentives for high tech products, encourages a patenting drive, requires foreign suppliers of IT security products to reveal source codes and other proprietary information, and uses government procurement to favor Chinese products. Despite charges that such policies are mercantilist and encourage technology theft the impacts on indigenous innovation are mixed: the authorities have back tracked on some measures and have actually improved their offer to the WTO's government procurement agreement. Foreign producers have gained from new spending on the shift to third generation mobile technology while losing market share in wind power and second generation telecoms equipment (Kennedy 2010).

Abroad, Chinese giants Huawei and ZTE have become major telecom equipment suppliers worldwide. Suspicions that Chinese-made equipment will be used to compromise national security have fed actions to block both trade and FDI in some countries. The Indian government temporarily blocked imports of Chinese equipment causing procurement problems for its rapidly expanding mobile phone network. Huawei resolved the issue by agreeing to demands to deposit source code in escrow. US politicians have claimed that Huawei is a company under the direction of the Chinese military and should be blocked from entering the supply chain of US military, law enforcement and the private sector. Since 2008 three Huawei bids have failed (for 2 Wire, a Motorola unit, and $3 \mathrm{Com}$ ) due to fears the bids would not secure regulatory approval. A supply contract with Sprint Nextel is also being challenged. Huawei is now trying a route used in the past by the Japanese: divert FDI to Canada and invest in R\&D in Canadian telecoms to develop acceptable bona fides in the US market (Sturgeon 2010).

At the industry level, therefore, we find both evidence of the growing assertion of Chinese economic power as well as missteps and misjudgments with unintended consequences suggestive of disagreements within the leadership. Heightened suspicion leads to linkage between the treatment of foreign companies in China and the treatment of Chinese entities abroad. The government has back tracked on some aspects of the techno-nationalist innovation strategy and compensated to some extent by improving its WTO offer on government procurement.

\section{International Monetary Cooperation, Exchange Rate Regimes and the IMF}

China's role in the international monetary system is clearly internationalist; so far it has worked within the system to advance its interest in voice consistent with its economic size. Conceived by Bretton Woods architects as the next best thing to a world central bank the IMF mandate was initially based on a system of fixed exchange rates which collapsed when major reserve currency countries were unwilling to change policies to maintain exchange rate equilibrium. Fixed and flexible exchange rate regimes proliferated and the IMF's role evolved to promote international monetary cooperation necessary to maintain orderly exchange rate arrangements and expand world trade. It conducts regular surveillance of members' macroeconomic policies, provides technical support and provides short term liquidity to members with balance of payments difficulties. As official capital flows were overtaken by private flows by the mid-1990s the IMF's resources shrank in relative terms and the nature of its borrowers changed. The advanced countries continued to dominate its decision making and determination of conditions on 
borrowers which increasingly were smaller developing countries with little say in how the Fund was run. ${ }^{8}$

These issues came to a head during the 1997-98 Asian financial crisis when rightly or wrongly the IMF was perceived to have deepened the crisis by treating Asian borrowers with liquidity problems as if they were insolvent with structural problems (Ito 2007). Resentful borrowers repaid their loans early and began self-insuring by accumulating foreign reserves larger than those needed to cover imports and short term liabilities.

By the time of the global financial crisis in 2008-09 the IMF's reduced resources and credibility problems were such that it was not a significant player. Its resources, at around \$250 billion, paled in comparison with Asia's central banks whose foreign exchange reserves totaled nearly $\$ 5$ trillion in 2010 (Table 2) and sovereign wealth funds who managed more than \$2 trillion in 2006 (Truman 2007). Central banks led by the US Federal Reserve Board were also active in bilateral swap arrangements to address short term liquidity problems.

G20 leaders resuscitated the Fund by restoring its resources to $\$ 1$ trillion and encouraging it to set up new facilities to help countries solve credit problems. ${ }^{9}$ The IMF streamlined its lending framework and conditionality, providing adjustment support through short term lending facilities through which countries qualifying on an ex ante basis can access loans immediately as well as other credit lines on precautionary bases without conditions. ${ }^{10}$

IMF governance reform agreed at the Seoul G20 summit in November 2010 will make China the third-largest shareholder. Changes are still needed to make Fund analysis and advice more independent of its shareholders and their political interests and to make it more accountable for its performance both to shareholders and the public (DeGregorio et al 1999). Without such reforms the large emerging market economies have been reluctant participants in solving IMF funding problems.

How will China use its increased clout? As it assumes more power in governance will it support enhanced IMF staff objectivity in surveillance of members' economic performance? Will the United States and China be willing to move discussions of their macroeconomic interdependence into the IMF? Or will China favor a regional institution, possibly with different rules, where it has more clout?

In the IMF China has both dragged its feet and proposed reform. The slow adjustment of its nominal exchange rate (Figure 1) has drawn strong US criticism with some arguing that 'rejection of a flexible exchange rate' is a direct challenge to the international monetary order (Bergsten et al 2008:17). China was also one of the last (along with the United States) to agree

\footnotetext{
${ }^{8}$ Even so, small countries have repeatedly indicated they find Fund surveillance and advice helpful even though large countries have tended to ignore it.

9 In April 2009 leaders authorized a one-time SDR allocation of \$250 billion and \$500 billion in new borrowing from Fund shareholders under the New Arrangements to Borrow (NAB). Japan and the EU each agreed to lend \$100 billion and China indicated its willingness to provide $\$ 40$ billion in other ways.

${ }^{10}$ Including (the short-term liquidity facility, or SLF, and the flexible credit line facility, or FCL, and the Precautionary Credit Line, or PCL.
} 
to an IMF evaluation of its financial system through the Financial Sector Assessment Program. In contrast, China actively pursued governance reforms to raise its voting strength and adopt the SDR as a super-sovereign reserve currency to provide an alternative way to reallocate its foreign exchange reserves. Central bank governor Zhou Xiaochuan (2009) argued that current arrangements relying on a single national currency are flawed because of the potential for conflicts between domestic goals and international responsibilities. As the dollar-based system has become more volatile, developing and emerging market economies have diverted foreign exchange reserves from more productive uses to self-insure. The United Nations Commission (2009) also proposed an expanded SDR, calibrated to the size of reserve accumulations, to head off an expected evolution towards a two- or three-country reserve system which they assert would be as unstable as the current US-based system. Using the SDR in this way would allow large holders of US government securities to diversify their holdings within the IMF thereby avoiding exchange market volatility (Bergsten 2009). These proposals have gained little traction because of the entrenched position of the US dollar; market participants have little enthusiasm for the SDR over the dollar and governments have shown little enthusiasm. The reserves buildup continues. And there are few signs that China and the United States are willing to move their discussions of their economic interdependence and its systemic implications out of ad hoc meetings and the Strategic and Economic Dialogue and into the IMF.

Regionally, China has been active in multilateralizing the Chiang Mai Initiative (CMIM), the regional emergency financing mechanism set up in 2000 as bilateral currency swap agreements among the members of ASEAN+3. The 1997-98 crisis crystallized awareness that much of East Asia's high savings were intermediated in the world's financial centers rather than in the region. One response was to develop regional bond markets. The 2003 Asian Bond Market Initiative was launched to encourage local currency issues and the Asian Bond Fund created a pool of foreign exchange reserves from member central banks to increase liquidity. In 2010 the CMI swaps, which now totaled $\$ 120$ billion with 80 percent contributed by China, Japan and South Korea, were pooled into the CMIM common fund, supported by governance and voting structures to make it accountable to its members. Like the IMF, CMIM will provide short term emergency financing to its members. A surveillance unit is to be in place by early 2011. Whether its methodology will be consistent with those of the IMF remains to be seen. If it is, governments will share information about their economic policies and performance with the surveillance unit and agree to an early warning system to prevent future crises. CMIM's highly concentrated 'ownership' means that China, Japan and South Korea will have the most say in its strategy and operations. And an indicator of its success will be members' willingness to reduce self-insurance.

Within China, changes are in train for domestic reasons that will bring about some alignment with the global rebalancing objective. China's investment-driven export-led growth is unsustainable. The economy needs to rebalance towards greater reliance on domestic demand. The heavy emphasis on investment is supported by under-priced inputs for energy, land, capital and the environment (Kuijs 2010; Huang 2010). Capital is priced by the central bank which manages interest rates to support exchange rate stability for exporters and which provide the government-owned banking system with generous and riskless spreads (Dobson and Kashyap 2006; Dobson 2009a; Prasad 2009). Powerful interests vested in investment- and export-led growth resist a more flexible yuan fearing it will shave already-thin profit margins. 
The $12^{\text {th }}$ Five Year Plan proposed in October 2010 signaled the Party's collective awareness of the need to restructure the economy. Changes in domestic policy are expected to increase imports and the weight of consumption relative to investment and net exports in GDP through policies to boost employment and household incomes through higher wages and greater labor mobility, higher public expenditures on health, education and pensions, better access to market finance for employment-creating SMEs and deregulation of service sectors currently dominated by large state monopolies. At the same time the "disinterested authoritarian capitalism" that has delivered China's material prosperity has entrenched interest groups that could block reforms to transfer wealth, undermine the impartiality and block reforms to respond to popular demands for greater political pluralism (Yao 2010).

The leadership recognizes that such key prices as the exchange rate and interest rates cannot be managed indefinitely and that more flexibility is required. Indeed the central bank characterizes abandoning the US dollar peg as a continuation of the managed exchange rate regime adopted in 1994 (Hu Xiaolian 2010). A more flexible exchange rate (assuming it would appreciate) would facilitate domestic economic rebalancing. Rebalancing is also necessary to ensure the safety of China's accumulated reserves which will lose value as the US dollar depreciates or if US inflation picks up and US bond prices decline (Yu Yongding 2009). In real terms, some argue the exchange rate has strengthened against the US dollar by almost 50 percent since 2005 (Economist 2010) as Chinese prices have risen much faster than those in North America. Change in the nominal rate, however, will be gradual and controlled, according to China's needs. Gradual internationalization of the yuan (through swap agreements with other central banks, increased foreign access to the interbank bond market, greater use of the yuan in trade finance) will facilitate more RMB-based international transactions. They also accept that eventually the RMB could become an international reserve currency. For this to happen, however, the capital account must be fully convertible which will open China to global capital flows from which it is now protected, and loosen control over monetary policy (Dobson and Masson 2009).

The question that remains is whether the $12^{\text {th }}$ Plan proposal and the G20 focus on rebalancing to include structural reform as well as currency adjustment will help address the powerful political interests vested in the state-dominated financial system, both inside and outside the Party, pushing for continued exchange rate and interest rate stability. Greater exchange rate flexibility is essential to develop a deep and liquid market-based financial system and more efficient use of capital in the increasingly complex industrial economy that underpins China's growing economic power and international influence.

\section{Development Finance and the World Bank}

The World Bank and the regional multilateral development banks provide development finance through loans and grants and technical assistance to developing countries to promote poverty reduction and economic development. The network of banks is more decentralized than the IMF system and the regional banks are largely run by countries in the regions. The World Bank is governed by its shareholders but developing countries criticize it for reflecting the development priorities imposed by the advanced countries rather than those of the developing countries themselves. Since 1980 China has had an harmonious relationship with the World Bank. China continues to borrow for projects ranging from energy efficiency and environmental 
projects to urban and rural development. In 2007 China became a net contributor to the World Bank's International Development Assistance mechanism and in 2010 its third-largest shareholder. A Chinese national is the World Bank's chief economist.

\section{Financial Market Oversight and Stability}

The global crisis highlighted the paradox between the national scope of financial supervision and the global reach of capital markets and institutions. While strong and modern national financial systems are essential to stable markets national regulators cannot prevent cross-border financial crises by acting on their own. They must coordinate and communicate among themselves. The Financial Stability Forum, set up by G7 governments after the Asian crisis, is based at the Bank for International Settlements and closely related to the Basel Committee, to facilitate such cooperation. But the institution lacked legitimacy and relied on voluntary implementation of its guidelines and recommendations. G20 leaders expanded its membership and changed its name to the Financial Services Board (FSB), charging it to work closely with the IMF in implementing its recommendations and guidelines through the Fund's surveillance and its Financial Sector Assessment Program (FSAP) which focuses on national financial systems and their prudential supervision.

China has been relatively passive in the financial supervisory debates and inactive in the region although a group of East Asian economists has recommended intensified supervision of financial institutions engaging in cross-border business and an Asian Financial Stability Dialogue to deepen regional financial integration (Asian Development Bank Institute 2009). It has yet to gain any traction however.

\section{Climate Change}

Together with the United States China is the world's largest absolute emitter of greenhouse gases while ranking far down the list of per capita emitters. China is a charter member of the UN Framework Convention on Climate Change and participated in the Copenhagen talks in December 2009 which ended with a last minute non-binding accord. It sees itself as part of the developing world in the divisions in negotiating measurement and verification of cuts in carbon emissions; it is an advocate of funding by the rich countries of funding for clean energy technology in developing countries and the Clean Development Mechanism and the establishment of offset markets. China was willing to commit only to what was best for China's development rather than to any global reduction targets. China and India also coordinated their positions at the talks. Nevertheless, domestic pressures to clean up the environment are pushing the government to act. The $12^{\text {th }}$ Plan will contain obligatory targets to increase renewable energy supplies to 15 percent of the primary energy mix and for 40-45 percent reduction by 2020 in carbon emissions as a ratio to GDP. Incentives will have to change on the demand side (such as the push towards production of hybrid and electric autos) and on the supply side an investment package of much as $\$ 740$ billion in an energy development plan over the next decade is reported.

The emphasis on industrial policies favoring renewable energy in the $12^{\text {th }}$ Plan has already attracted complaints of unfair trade from US interest groups but it could also lead to innovations in climate change policy. Western standards of living cannot be replicated with existing technologies so frugal innovations will be at a premium. All levels of government are 
gearing up to become first movers in renewable production and innovation. Along with India, successes with frugal energy-efficient innovations could lead to suggestions for new global standards.

In deep ocean mining, a tangentially relevant area, we find an example where China has accepted and is abiding by United Nations regulatory authority. In its search for precious metals, China has become a player in deep ocean mining of polymetallic suphides found around hydrothermal vents and used in batteries and electronics of computers, cellphones and hybrid cars. Recently the government filed an application with the International Seabed Authority, created under the 1982 UN Convention on the Law of the Sea, to extract ore from an underwater ridge in the Indian Ocean (Byers 2010).

\section{Asian Regionalism}

Within the Asian region China's charm offensive saw it play a relatively passive role in regional institutions while competing with Japan, India and the United States outside. It faces determined efforts by the ASEAN 'core' economies to divert this competition into regional cooperation in the nascent regional financial and trade institutions. But progress on the 2015 target for an East Asian community proposed by the 2001 Vision Group is slow; decisions rely on consensus and activity is focused more on members' interests than on advancing common rules or standards. Trading patterns are lop-sided in regional production networks with China a major importer from its neighbors but competing directly with some of them in final goods markets. The expansion of ASEAN+3 in 2004 over China's objections to include India, Australia and New Zealand to form the East Asian Summit (EAS) cuts two ways in that this and other cooperative institutions serve its objective of developing closer friendly relationships in the neighborhood but US and Indian inclusion provide a counter-balance in the EAS.

Good relationships with the neighborhood allow China to concentrate on its many distractions at home. When government representatives talk about China's "peaceful development" they are at pains to elaborate that this means no expansion, no hegemony and no alliances. The message has the implicit sub-text that if China gets its domestic development right its influence will automatically expand with its growing economic and political clout. The cooperative networks also help to address the ambivalence that many feel about China, summed up by the observations of some Asian neighbors who say, "Don't call China a threat," while others admonish, "Don't forget China is a threat."

China's more assertive behavior recently on resource and boundary issues has alarmed its neighbors. The tone and behavior toward regional partners appears to be motivated by growing confidence and a desire to reverse historical humiliation. The territorial dispute with Japan over the Diaoyu/Senkaku Islands suggests the two governments apply different frameworks; China uses historical evidence while Japan takes a more legalistic approach. The clash, characterized as "shock and awe" and a test of China's peaceful rise doctrine (Funabashi 2010), raised questions whether such disputes can be resolved. What does this mean? Is the long held conviction weakening that political stability is necessary for wealth and development as stepping stones to power and influence? Or are we seeing jostling in the runup to the 2012 leadership transition? China's next top leaders are largely from civilian ranks of new entrepreneurs and the communist youth league rather than the PLA or the foreign policy 
establishment. The resulting credibility vacuum on national security may encourage them to appear to be tough-minded; figures in defense and foreign affairs are also moving to fill the vacuum (Page 2010).

It remains to be seen whether the leadership transition will be followed by equilibrium or by more external tensions. The current uncertainty is potentially counter-productive for China in that its neighbors react by moving closer to the United States for reassurance. While China is driving East Asia's economic integration and its diplomatic influence is spreading it is unlikely that China will replace the United States as the region's guarantor of peace and stability. In an October 2010 speech (Clinton 2010b) Secretary of State Hillary Clinton made clear that the United States is increasing its participation in the region's institutions. It seems likely that Japan, India and Russia will also resist attempts to assert regional dominance.

\section{Conclusions and Looking to the Future}

In conclusion, China's interaction with the international economic institutions reflects its leaders' own conclusion that in a globalized world China must learn from and participate in the international organizations. China's views and involvement at both the regional and global levels are summarized in Table 3. Up to now China has largely played by the existing rules of multilateralism. Its participation in the international economic system is constructive. In the Asian region China has been receptive to its neighbors' initiatives to develop cooperative regional institutions.

China, now indisputably one of the world's leading economic powers, has to decide how it will use that power. Just playing by the rules is insufficient in an interdependent world economy. The existing institutions were created by the western powers but allow for new participants and leadership. In a multi-polar world no one power can ensure the global interest (or get what it wants) by itself. Partnerships, coalitions and networks may be required in which the emerging powers take on more responsibility for providing global public goods. Yet China's demonstrated record is that of a still-poor developing country pursuing its own interests. Sometimes these interests overlap with the collective interest, as was the case with the 2008 stimulus package, China's super-sovereign reserve currency proposal, and the compromise between the United States and the BASICs to create the non-binding accord at Copenhagen. Sometimes these interests have collided, such as when China backed India in blocking the deal that could have concluded the Doha round. Overall, however, China has mostly been a relatively passive participant with the ideas and leadership provided by others.

The picture is somewhat different in the region where China has actively participated in CMIM and negotiated the FTA with ASEAN. But the plethora of regional institutions reflects the underlying rivalries among China, Japan and India. China's assertion of historical claims to territory and natural resources has been counter-productive.

The analysis suggests four conclusions about China and global economic governance. First, the relationship is two-way; China has been a major beneficiary of the institutions and their rules and standards as it has opened and modernized the economy. There are few signs that because of its sheer size and potential influence on world trade and finance, China is reshaping the institutions and their rules and norms to suit itself. China is a strong and vocal supporter of 
more democratic behavior and use of consensus in the institutions and for more respect for differences among countries - laudable values to be sure but they avoid the reality that effective multilateral governance sometimes requires tough decisions in the interests of global stability.

Second, history matters. There is little evidence that China is (yet) willing to modify its own economic policies in recognition of international interdependence, with two exceptions: foregoing nominal exchange rate devaluation in the Asian crisis and presenting the large stimulus package in 2008 as "good for China and good for the world". Most evidence suggests China is still primarily focused on safeguarding its sovereignty and advancing its own development objectives.

Some argue China's foot dragging on modernizing the exchange rate regime is at the expense of the international order. The Chinese leadership openly agrees that change is required but sets its own pace according to the political importance of steady growth in output and employment. The transition in the exchange rate regime will not be easy as it will need to be accompanied by extensive domestic restructuring, challenging powerful interests vested in the status quo. Internationalizing the RMB will reduce some of the pressure but the pace and extent will be limited by capital controls and heavy exchange rate management. The related buildup of foreign exchange reserves may be seen in China to be a source of economic power that fits well with state capitalism but it is an increasingly inefficient allocation of capital.

Third, politics matter. China's relationship with the United States is of central importance. US re-commitment to multilateralism is welcome but the United States also needs to put its own house in order if it is to continue to be a credible leader of the economic order. As a major deficit country it lacks a credible plan for medium-term fiscal consolidation, and like China's exchange rate appreciation, action is constrained by domestic politics. Quantitative easing in November 2010 may have been necessary to head off deflation but it triggered disruptive capital flows seeking higher returns in emerging economies. Looking ahead, just as it could take a decade for the United States to learn to live within its means, China's internal rebalancing will take time to change policies and institutions. Branding China as a long-term adversary could become a self fulfilling prophecy and would be counter-productive. Indeed the interests of both countries and that of the global commons are best served by strengthening the global institutions in ways that include China.

Fourth, other economies in the region will have to adjust to the rebalancing required in both the United States and China by relying more on domestic and regional demand. Regional institutions can help promote such adjustment. Greater reliance on partnerships and positive sum outcomes by the United States signals a cooperative route forward in the region with China as a more active player. Much will depend, however, on whether the United States sets the example for this new reality by its willingness to bargain and compromise to accommodate China's interests. 


\section{References}

Anderlini, Jamil and Paul Betts (2010). "China forced to put a value on its 'foreign' friends," Financial Times July 21.

Asian Development Bank Institute. (2009). Recommendations of Policy Responses to the Global Financial and Economic Crisis for East Asian Leaders. (http://www.adbi.org) accessed 25 March 2009.

Asian Development Bank. (2008). Emerging Asian Regionalism. Manila: Asian Development Bank.

Bardhan, Pranab (2005). “China, India Superpower? Not so Fast!” YaleGlobal Online, October 25 .

Bergsten C.F. (2009). We Should Listen to Beijing's Currency Idea. Financial Times. April 9.

Bergsten C.F., Freeman C., Lardy N.R. and Mitchell D.J. (2008). China's Rise: Challenges and Opportunities, page 17. Washington, DC: Peterson Institute for International Economics and Center for Strategic and International Studies.

Byers, Michael, 2010. "It Came from Beneath the Sea", Globe and Mail, July 19.

Clinton, Hillary Rodham (2010a). Speech to Council on Foreign Relations, Washington, DC, September 8 .

Clinton, Hillary Rodham (2010b). “America’s Engagement in Asia-Pacific”, October 28.

Cohen, Jerome A. (2010). "How China Handles 'State Secrets' Prosecutions: Xue Feng's Case", South China Morning Post, July 21.

Corbett, Jenny and Takatoshi Ito (2010). "What China Should Learn from Japan", Vox EU, April 30 .

De Gregorio J., Eichengreen B., Ito, T. and Wyplosz C. (Eds.), (1999). An Independent and Accountable IMF. Geneva Reports on the World Economy 1. Geneva: International Center for Monetary and Banking Studies.

Dobson, Wendy (2009a). Gravity Shift: How Asia's New Economic Powerhouses Will Shape the $21^{\text {st }}$ Century, Toronto: Rotman University of Toronto Press.

Dobson, Wendy (2009b). "Window of Opportunity Opens: Asian and American Views of the International Architecture," Asian Economic Policy Review, 4:271-287.

Dobson, Wendy and Anil Kashyap (2006). "The Contradictions in China's Gradualist Banking Reforms," Brookings Papers on Economic Activity, Washington: Brookings Institution, No. 2. 
Dobson, Wendy (1991). Economic Policy Coordination: Requiem or Prologue? Washington, DC: Institute for International Economics.

Dobson, Wendy and Paul Masson (2009). "Will the Renminbi become a world currency?" China Economic Review, 20:1, 124-35.

Economist, The (2010). "Nominally Cheap or Really Dear?” November 6.

Economy, Elizabeth (2010). “The Game Changer”, Foreign Affairs, November/December, 14252.

Eichengreen Barry (2009). The G20 and the Crisis. (http://www.voxeu.org/index.php?q=node/3160) accessed 15 March 2009.

Friedman, George (2009). The Next 100 Years: A Forecast for the $21^{\text {st }}$ Century, New York: Anchor Books.

Funabashi, Yoichi (2010). "Japan-China relations stand at ground zero", The Asahi Shimbun, October 9.

Hufbauer, Gary and Robert Z. Lawrence (2010). "Let's Do a Doha Deal," East Asia Forum, July 22 available at www.eastasiaforum.org/2010/07/22/lets-do-a-doha-deal/.

$\mathrm{Hu}$, Xiaolian (2010). “A managed floating exchange rate regime is an established policy”, July 15, available at pbc.gov.cn/publish/English/956/2010.

Huang, YiPing (2010). Asian Economic Forum. [tbc]

Ito Takatoshi (2007). "The Asian Currency Crisis and the International Monetary Fund, 10 Years Later: An Overview”. Asian Economic Policy Review. 2(1), 16-49.

Jacques, Martin (2009). When China Rules the World, London: Penguin Group.

Kagan, Robert (2008). The Return of History and the End of Dreams, New York: Knopf.

Kawai, Masahiro and Peter A. Petri (2010). "Asia's Role in the Global Economic Architecture," ADBI Working Paper Series, No. 235, Tokyo: Asian Development Bank Institute, August.

Kawai, Masahiro and Ganeshan Wignaraja (2009). "Asian FTAs: Trends and Challenges”, Asian Development Bank paper, March 12.

Kennedy, Scott (2010). "Indigenous Innovation: Not as scary as it sounds," China Economic Quarterly, September, 15-20. 
Kent, Ann, 2007. Beyond Compliance: China, International Organizations and Global Security, Stanford:Stanford University Press, 105-07.

Keohane, Robert O. (2002). “Global Governance and Democratic Accountability,” manuscript.

Kuijs, Louis (2010). [tbc]

Maddison, Angus (2006). "Asia in the World Economy 1500-2030 AD”, Asian Pacific

Economic Literature, 20:2: 1-37.

Mahbubani Kishore (2008). The New Asian Hemisphere: The irresistible shift of the global power to the East. New York: Public Affairs.

Moran, Theodore H. (2010). China's Strategy to Secure Natural Resources: Risks, Dangers, and Opportunities, Policy Analyses in International Economics 92, Washington: Peterson Institute for International Economics.

Nye, Joseph (2004). Soft Power. New York: Public Affairs.

Page, Jeremy (2010). "PLA Gains Political Clout”, Wall Street Journal, October 5.

Park Yung Chul and Cheong I. (2008). "The Proliferation of FTAs and Prospects for Trade Liberalization in East Asia." In: Eichengreen Barry, Wyplosz Charles and Park Yung Chul, (Eds), China, Asia, and the New World Economy. Oxford: Oxford University Press.

Pei, Minxin (2009). “Think Again: Asia’s Rise”, Foreign Policy, July/August.

Prasad, Eswar (2009). "Is the Chinese Growth Miracle Built to Last?" China Economic Review, 20:1. 103-23.

Posen, Adam (2010). “The Realities and Relevance of Japan's Great Recession” Working Paper 10-7, Washington DC: Peterson Institute, June.

Steinfeld, Edward S. (2010). Playing Our Game: Why China's Rise Doesn't Threaten the West, Oxford: Oxford University Press.

Sturgeon, Jamie (2010). “ Huawei Joins Canadian Tech Incubator”, Financial Post, August 26.

Truman E.M. (2007). Sovereign Wealth Funds: The need for greater transparency and accountability. Policy Briefs in International Economics, PB07-06, (http://www.petersoninstitute.org) accessed 15 February 2009.

Truman E. M. (2006). Rearranging Chairs and Shares. In: Truman EM (ed), Reforming the IMF for the $21^{\text {st }}$ Century. Washington, DC: Peterson Institute for International Economics. 
U.S. White House (2009). "Remarks by President Barack Obama at Suntory Hall”, November 14 available at www.whitehouse.gov/briefing

Wanandi J. and Yamamoto T. (2008). East Asia at a Crossroads. Tokyo: Japan Center for International Exchange.

Wang, Hongying and James N. Rosenau (2009). "China and Global Governance," Asian Perspective 33(3), 5-39.

United Nations (2009). The Commission of Experts on Reforms of the International Monetary and Financial System: Recommendations, available at (http://www.un.org/ga/president/63/commission/financial_commission.shtml).

United States Trade Representative (2009). Letters to Hon. Nancy Pelosi and Sen. Richard Byrd notifying of the President's intention to enter into negotiations of Trans-Pacific Partnership Agreement, December 12, available at www.ustr.gov/tpp.

Xinhua (2010a). "Hu calls for balanced global economic growth," Toronto, June 28.

Xinhua (2010b). "Commentary: BRICs dialogue conducive to global economic governance”, April 16.

Yao Yang (2010). "The End of the Beijing Consensus," Foreign Affairs Snapshot, February 2 available at www.foreignaffairs.org.

Yu Keping, 2009. Democracy is a Good Thing," Washington, DC: Brookings Institution Press.

Yu Yongding (2009). "China's Policy Responses to the Global Financial Crisis”, Snape Lecture, Melbourne, November 25.

Zhang, Yongjin (2005). “China Goes Global,” London: The Foreign Policy Centre, April.

Zhang, Yunling and Tang Shiping (2005). "China’s Regional Strategy,” David Shambaugh, Ed., Power Shift: China and Asia's New Dynamics, Los Angeles: University of California Press, 4868.

Zhou X (2009). Reform the International Monetary System. (http:www.pbc.gov.cn/english) accessed 25 March 2009.

Zoellick, Robert B., 2010. "Remarks for Celebration of the $30^{\text {th }}$ Anniversary of China-World Bank Partnership", Beijing: World Bank Group, September 13. 
Figure 1. Currency movements, US dollar to local currency (base=January 2007)

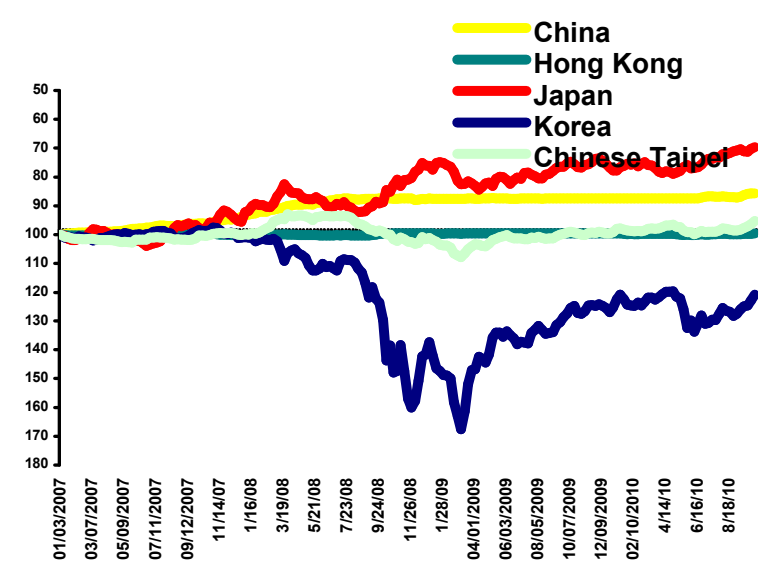

Table 1. China's Bilateral Trade Agreements

\begin{tabular}{|l|l|l|}
\hline Implemented & Under Negotiation & Feasibility Study \\
\hline China-ASEAN & China-Australia & China-India \\
\hline China-Chile & $\begin{array}{l}\text { China-Gulf Cooperation Council } \\
(\text { GCC })\end{array}$ & China-Japan-Korea \\
\hline China-Costa Rica & China-Iceland & China-Korea \\
\hline CEPA-Hong Kong & China-Norway & China-Switzerland \\
\hline China-New Zealand & & \\
\hline China-Pakistan & & \\
\hline China-Peru & & \\
\hline China-Singapore & & \\
\hline
\end{tabular}

Sources: China Ministry of Commerce; Schott 2010. 
Table 2

\begin{tabular}{|c|c|c|c|}
\hline \multicolumn{4}{|c|}{ Foreign Exchange Reserves minus Gold (billion US \$) } \\
\hline & May 2010 & $\%$ of Nominal GDP & Months of Imports \\
\hline Australia & 33.21 & 3.3 & 2.1 \\
\hline China & $2,456.19$ & 49.3 & 28.6 \\
\hline Hong Kong & 256.10 & 121.6 & 8.3 \\
\hline Indonesia & 71.75 & 13.3 & 8.1 \\
\hline Japan & $1,011.61$ & 20.0 & 18.8 \\
\hline Korea & 270.14 & 32.4 & 8.5 \\
\hline Malaysia & 94.11 & 48.8 & 7.7 \\
\hline Singapore & 198.36 & 108.8 & 8.6 \\
\hline Thailand & 140.22 & 53.1 & 11.1 \\
\hline United States & 113.13 & 0.8 & 0.7 \\
\hline
\end{tabular}

Source: IMF 
Table 3. China, global and regional public goods

\begin{tabular}{|c|c|c|c|}
\hline Global Institution & Mandate & $\begin{array}{l}\text { Related Asian regional } \\
\text { activities }\end{array}$ & China's views/actions \\
\hline G20 & $\begin{array}{l}\text { Premier forum for } \\
\text { economic management }\end{array}$ & & $\begin{array}{l}\text { Provide long-term } \\
\text { governance.. .proactive } \\
\text { planning; Accelerate new } \\
\text { international financial } \\
\text { order; Build open and free } \\
\text { global trading regime }\end{array}$ \\
\hline WTO & $\begin{array}{l}\text { Trade liberalization; } \\
\text { principles of transparency, } \\
\text { non-discrimination; } \\
\text { dispute settlement } \\
\text { mechanism }\end{array}$ & $\begin{array}{l}\text { Regional and sub-regional } \\
\text { trade agreements; } \\
\text { proposals for trans-Pacific } \\
\text { FTA }\end{array}$ & $\begin{array}{l}\text { FTAs driven by foreign } \\
\text { policy objectives } \\
\text { No expressed interest in } \\
\text { trans-Pacific FTA }\end{array}$ \\
\hline World Bank & $\begin{array}{l}\text { Promote development; } \\
\text { reduce poverty }\end{array}$ & $\begin{array}{l}\text { Asian Development Bank } \\
\text { focused on regional } \\
\text { development; } \\
\text { infrastructure lending }\end{array}$ & $\begin{array}{l}\text { World Bank partner; } \\
\text { increasing aid donor }\end{array}$ \\
\hline IMF & $\begin{array}{l}\text { Promote international } \\
\text { monetary cooperation; } \\
\text { Maintain orderly exchange } \\
\text { rate regimes; Expand } \\
\text { world trade; } \\
\text { Financial and technical } \\
\text { assistance to members } \\
\text { with balance of payments } \\
\text { problems; Ongoing } \\
\text { macroeconomic } \\
\text { surveillance (Art. IV) }\end{array}$ & $\begin{array}{l}\text { CMIM provides } \\
\text { emergency financing for } \\
\text { Asian members with BOP } \\
\text { problems } \\
\text { AMRO to carry out } \\
\text { surveillance of members' } \\
\text { policies }\end{array}$ & $\begin{array}{l}\text { Long-term vision for IMF } \\
\text { as provider of global } \\
\text { reserve currency not tied } \\
\text { to any one country's } \\
\text { currency } \\
\text { RMB as one of several } \\
\text { reserve currencies }\end{array}$ \\
\hline Financial Stability Board & $\begin{array}{l}\text { Set capital, liquidity } \\
\text { standards; harmonize } \\
\text { regulatory frameworks } \\
\text { across borders; oversight } \\
\text { and monitoring }\end{array}$ & $\begin{array}{l}\text { Asian countries to create } \\
\text { Asian FSB as mechanism } \\
\text { for regional cooperation } \\
\text { on regulatory reform/ } \\
\text { consistent with global FSB }\end{array}$ & \\
\hline $\begin{array}{l}\text { UN Framework } \\
\text { Convention on Climate } \\
\text { Change (UNFCCC) }\end{array}$ & & $\begin{array}{l}\text { China-India coordinated } \\
\text { position in UNFCCC talks }\end{array}$ & $\begin{array}{l}\text { Targets for renewables and } \\
\text { reduced carbon intensity } \\
\text { likely "pillars" of } 12^{\text {th }} \text { Plan }\end{array}$ \\
\hline
\end{tabular}

